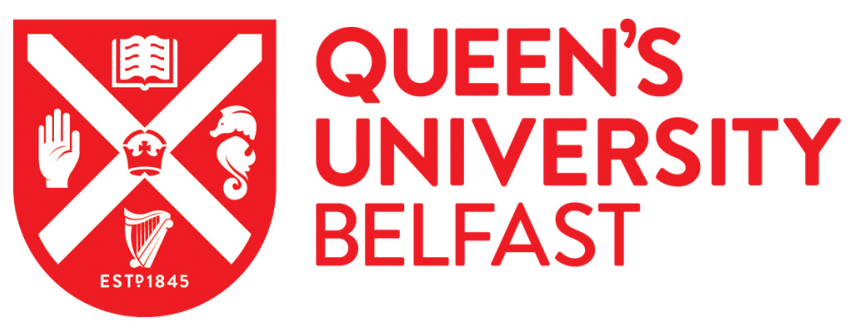

\title{
Response to Park et al. reply to "Back to the future: routine morphological assessment of the tumour microenvironment is prognostic in stage II/III colon cancer in a large population-based study"
}

Hynes, S. O., Coleman, H. G., Kelly, P. J., Dunne, P. D., Salto-Tellez, M., \& Loughrey, M. B. (2017). Response to Park et al. reply to "Back to the future: routine morphological assessment of the tumour microenvironment is prognostic in stage II/III colon cancer in a large population-based study". Histopathology. https://doi.org/10.1111/his.13221

Published in:

Histopathology

Document Version:

Peer reviewed version

Queen's University Belfast - Research Portal:

Link to publication record in Queen's University Belfast Research Portal

Publisher rights

Copyright 2017 Wiley.

This work is made available online in accordance with the publisher's policies. Please refer to any applicable terms of use of the publisher.

\section{General rights}

Copyright for the publications made accessible via the Queen's University Belfast Research Portal is retained by the author(s) and / or other copyright owners and it is a condition of accessing these publications that users recognise and abide by the legal requirements associated with these rights.

Take down policy

The Research Portal is Queen's institutional repository that provides access to Queen's research output. Every effort has been made to ensure that content in the Research Portal does not infringe any person's rights, or applicable UK laws. If you discover content in the Research Portal that you believe breaches copyright or violates any law, please contact openaccess@qub.ac.uk. 
DR SEAN HYNES (Orcid ID : 0000-0002-3092-7945)

Received Date : 16-Mar-2017

Accepted Date : 19-Mar-2017

Article type : Correspondence

Response to Park et al. reply to "Back to the future: routine morphological assessment of the tumour microenvironment is prognostic in stage II/III colon cancer in a large population-based study"

Keywords: colorectal cancer, inflammation, prognosis, stroma, survival

$16^{\text {th }}$ March 2017

Dear Editor,

We thank Park et al for their interest in our work and for bringing to our attention their alternative microenvironmental score for assessing colorectal cancer prognosis. ${ }^{1-3}$ We are largely in agreement with many of the points raised. The scoring systems proposed by these two studies share many similarities, highlighting the importance of the non-epithelial tumour components and combining assessments of peritumoral inflammatory response and tumour stromal percentage to derive a prognostically valuable fibroinflammatory or microenvironmental score. Despite the overall similarity, a number of small, albeit clinically important, differences lie in the methodologies chosen for assessment of each individual parameter, and in the statistical approaches used.

As Park et al acknowledge, there is considerable evidence that it is the lymphoid This article has been accepted for publication and undergone full peer review but has not been through the copyediting, typesetting, pagination and proofreading process, which may lead to differences between this version and the Version of Record. Please cite this article as doi: 10.1111/his.13221

This article is protected by copyright. All rights reserved. 
composition of the peritumoral inflammatory population (rather than general inflammation) that is of most prognostic influence for colorectal cancer, although reproducibility is likely inferior. ${ }^{4-7}$ Their working group have previously reported assessment of both peritumoral lymphocytic inflammation (by Jass method) and general inflammation (by Klintrup-Makinen method) to have good reproducibility (inter-observer intraclass correlation coefficients 0.71 and 0.81 respectively). ${ }^{8}$ Although we found good intraobserver reproducibility, we also observed poor interobserver reproducibility for assessment of peritumoral lymphoid infiltrates, and did not evaluate general peritumoral inflammation in our study. There are a growing number of translational studies highlighting that the prognostic value of the inflammatory microenvironment can be dictated by the relative abundance of specific immune-cell lineages. ${ }^{9-11}$ We acknowledge that general inflammation may indeed be more easily and reproducibly assessed on haematoxylin and eosin (H\&E)-stained slides and that immunohistochemistry, aided by digital image analysis, may be required for most accurate immunoscoring of lymphoid populations. This is deserved of further study.

A further distinction between the two studies is that, unlike the microenvironmental score proposed by Park et al, our score includes an assessment of peritumoral lymphoid aggregates, or Crohn's disease-like reaction (CLR). Supported by Klintrup et al, we consider this sufficiently independent of peritumoral diffuse lymphoid reaction to warrant inclusion as a separate parameter, adding prognostic value. ${ }^{12}$ Our study employed the wellestablished semi-quantitative assessment proposed by Graham and Appelman, which we found to be reproducible. ${ }^{13}$ The cited study by Kim et al advocates assessment of peritumoral lymphoid aggregates by size or density. ${ }^{14}$ However this study methodology employed digital image analysis of scanned slides, to allow the required precise measurements for this classification, and is therefore not immediately applicable to routine histopathology practice at the current time. For this reason, this method of assessment was not considered in our study.

We adopted both global and focal assessments of tumour stromal percentage (TSP), as reported previously. ${ }^{15-17}$ We found global, but not focal, assessment to be highly reproducible and prognostic. As discussed, we are aware this contradicts findings from two previous studies also highlighted by Park et al, both describing excellent reproducibility of

This article is protected by copyright. All rights reserved. 
the refined focal method. ${ }^{16,17}$ Key to the focal TSP method is identification of the most invasive point of tumour and, on post-study case discussion, this varied considerably between the four pathologists in our study, profoundly influencing assessments and reproducibility. This is likely to be an even greater problem in everyday reporting practice, with more tumour slides to evaluate per case. Also taking into consideration frequent heterogeneity of tumour morphology, we consider the global TSP method to be more valuable than the focal TSP method.

Finally, some differences in the statistical approaches to the two scores also exist. Park et al evaluated five year survival, whereas we evaluated prognosis up to ten years post-diagnosis, and retained confounders such as adjuvant chemotherapy in our multivariate model. They found TSP to be rare and not prognostic in a scenario of high general inflammation (Klintrup-Makinen) score. ${ }^{3}$ Leaving aside the differences in assessment methodologies outlined above, we have now replicated this analysis, and also found a high global TSP to be of greater prognostic importance in the context of low peritumoral inflammation (unadjusted HR 1.63, 95\% Cl 1.11-2.40). However, as outlined in Table 5 of our results, taking into consideration all three measures (global TSP, peritumoral inflammation and CLR) resulted in the strongest association with colorectal cancer-specific survival. Perhaps of most importance, in multivariate models, we found a stronger association between colorectal cancer-specific survival and the highest fibroinflammatory score in our study (HR 2.44, $95 \% \mathrm{Cl}$ 1.56-3.81), than that noted for the highest Glasgow microenvironmental score (HR 1.93, 95\% Cl 1.36-2.73), although the confidence intervals do overlap. ${ }^{3}$

Despite differences in methodologies employed, the similar approaches adopted by the two groups draw similar conclusions and further highlight the potential utility of inflammatory and stromal assessments as valuable prognostic markers in colorectal cancer, alone or in some combination. We agree further independent studies are required for validation and determination of optimal methods of assessment.

This article is protected by copyright. All rights reserved. 
Yours sincerely,

\author{
Dr. Seán O Hynes ${ }^{1}$, \\ Dr. Helen G Coleman², \\ Dr. Paul J Kelly $y^{1,3}$ \\ Dr. Philip D Dunne ${ }^{1}$
}

Professor Manuel Salto-Tellez $z^{1,3}$

Dr. Maurice B Loughrey ${ }^{1,3}$

${ }^{1}$ Northern Ireland Molecular Pathology Laboratory, Centre for Cancer Research and Cell Biology, Belfast, UK. ${ }^{2}$ Centre for Public Health, Queen's University Belfast, UK. ${ }^{3}$ Department of Tissue Pathology, Royal Victoria Hospital, Belfast Health and Social Care Trust, Belfast, UK.

\title{
References
}

1. Hynes SO, Coleman HG, Kelly PJ, et al. Back to the future: routine morphological assessment of the tumour microenvironment is prognostic in stage II/III colon cancer in a large population-based study. Histopathology 2017.

2. Park JH, Roxburgh CS, Edwards J, Horgan PG, McMillan DC. In reply to "Hynes S.O. et al. Back to the future: routine morphological assessment of the tumour microenvironment is prognostic in stage II/III colon cancer in a large population-based study". Histopathology 2017.

3. Park JH, McMillan DC, Powell AG, et al. Evaluation of a tumor microenvironment-based prognostic score in primary operable colorectal cancer. Clin Cancer Res 2015;21:882-888.

4. Vayrynen JP, Tuomisto A, Klintrup K, Makela J, Karttunen TJ, Makinen MJ. Detailed analysis of inflammatory cell infiltration in colorectal cancer. Br J Cancer 2013;109:1839-1847.

5. Vayrynen JP, Sajanti SA, Klintrup K, et al. Characteristics and significance of colorectal cancer associated lymphoid reaction. Int J Cancer 2014;134:2126-2135.

6. Roxburgh CS, McMillan DC. The role of the in situ local inflammatory response in predicting recurrence and survival in patients with primary operable colorectal cancer. Cancer Treat Rev 2012;38:451-466.

7. Richards $\mathrm{CH}$, Flegg KM, Roxburgh CS, et al. The relationships between cellular components of the peritumoural inflammatory response, clinicopathological characteristics and survival in patients with primary operable colorectal cancer. Br J Cancer 2012;106:2010-2015.

8. Roxburgh CS, Salmond JM, Horgan PG, Oien KA, McMillan DC. Tumour inflammatory infiltrate predicts survival following curative resection for node-negative colorectal cancer. Eur J Cancer 2009;45:2138-2145.

This article is protected by copyright. All rights reserved. 
9. Fridman WH, Pages F, Sautes-Fridman C, Galon J. The immune contexture in human tumours: impact on clinical outcome. Nat Rev Cancer 2012;12:298-306.

10. Galon J, Mlecnik B, Bindea G, et al. Towards the introduction of the 'Immunoscore' in the classification of malignant tumours. J Pathol 2014;232:199-209.

11. Nosho K, Baba Y, Tanaka N, et al. Tumour-infiltrating T-cell subsets, molecular changes in colorectal cancer, and prognosis: cohort study and literature review. J Pathol 2010;222:350-366.

12. Klintrup K, Makinen JM, Kauppila S, et al. Inflammation and prognosis in colorectal cancer. Eur J Cancer 2005;41:2645-2654.

13. Graham DM, Appelman HD. Crohn's-like lymphoid reaction and colorectal carcinoma: a potential histologic prognosticator. Mod Pathol 1990;3:332-335.

14. Kim JH, Kim KJ, Bae JM, et al. Comparative validation of assessment criteria for Crohn-like lymphoid reaction in colorectal carcinoma. J Clin Pathol 2015;68:22-28.

15. Mesker WE, Junggeburt JM, Szuhai K, et al. The carcinoma-stromal ratio of colon carcinoma is an independent factor for survival compared to lymph node status and tumor stage. Cell Oncol 2007;29:387-398.

16. Huijbers A, Tollenaar RA, v Pelt GW, et al. The proportion of tumor-stroma as a strong prognosticator for stage II and III colon cancer patients: validation in the VICTOR trial. Ann Oncol 2013;24:179-185.

17. Park JH, Richards CH, McMillan DC, Horgan PG, Roxburgh CS. The relationship between tumour stroma percentage, the tumour microenvironment and survival in patients with primary operable colorectal cancer. Ann Oncol 2014;25:644-651.

This article is protected by copyright. All rights reserved. 